\title{
ASEAN Journal of Science and Engineering
}

Journal homepage: http://ejournal.upi.edu/index.php/AJSE/

\section{Eco-Friendly Batteries from Rice Husks and Wood Grain}

\author{
A.M. Nurjamil ${ }^{1}$, N.A. Wolio ${ }^{1}$, R. N. Laila ${ }^{1}$, S. A. Rohmah ${ }^{1}$, \\ Asep Bayu Dani Nandiyanto ${ }^{1, *}$, Sri Anggraeni ${ }^{1}$, Tedi Kurniawan ${ }^{2}$ \\ ${ }^{1}$ Universitas Pendidikan Indonesia, JL. Dr. Setiabudi No. 229, Bandung, 40154, Indonesia \\ ${ }^{2}$ Engineering Technology Department, Community College of Qatar, Qatar \\ Correspondence: E-mail: nandiyanto@upi.edu
}

\begin{abstract}
A B S T R A C T
The purpose of this study was to find out the carbon influence of rice husks and wood grain as electrolyte absorbers on large voltage and battery life. The battery fabrication procedure is as follows: (1) Preparing sixteen used batteries with a 1.5 Volt voltage, (2) Making $\mathrm{NaCl}$ solution with percentages of $10,20,30$, and $40 \%$, (3) Drying rice husks and wood grain until drying, (4) Carbonizing rice husks and wood grain, (5) Smoothing rice husks and carbonated wood grain, (6) Mixing rice husk, wood grain, and electrolyte solution, (7) Remove the contents of the used battery and wash it thoroughly, (8) Insert carbon from rice husks and wood grain. (9) Perform the process of closing the battery with the battery cover, (10) Measuring the battery voltage using an Avometer. This research shows that carbon derived from rice husks and wood grain can generate electrical voltage, but the resulting voltage is still low compared to commercial batteries. In addition, batteries with electrolyte solutions that have a salt percentage of $10 \%$

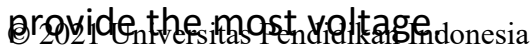

\begin{tabular}{l}
\hline A R T I C L E I N F O \\
\hline Article History: \\
Submitted/Received 06 Nov 2021 \\
First revised 07 Des 2021 \\
Accepted 25 Feb 2021 \\
First available online 27 Feb 2021 \\
Publication date 01 Mar 2021 \\
\hline Keyword: \\
Battery, \\
Biomass, \\
Rice husk, \\
Voltage, \\
Wood grain
\end{tabular}

A R T I C L E I N F O

First revised 07 Des 2021

Publication date 01 Mar 2021

Wood grain 


\section{INTRODUCTION}

Rice production in Indonesia is very abundant, which is about 67.31 million tons per year and the total potential of rice husks reaches 16 million tons per year (Yuliza, et al., 2013). The total production of saw wood in Indonesia reaches 2.6 million $\mathrm{m}^{3}$ per year assuming the amount of waste produced is $54.24 \%$ of the total production (Jamilatun, et al., 2010). Therefore, the potential of biomass can be utilized as a source of renewable energy.

Currently, research on batteries from various biomass has been conducted. Merbau and matoa sawdust have potential as bio-batteries but the resulting voltage is still low (Ernawati, et al., 2019). Banana skin has a higher voltage value than durian skin (Muhlisin \& Muh, 2015). Porous potato biomass as a potassium-ion battery anode produces excellent performance (Cao, et al., 2019). Lithium ion battery anodes derived from green tea leaf biomass exhibit a very capable capacity (Han, et al., 2014). Carbon batteries made from hemp fiber and corn cobs as lithium battery anode material showed excellent and stable capacity (Jiang, et al., 2016). However, research on batteries that use rice husks and wood grain as adsorbent agents of electrolyte solutions does not yet exist.

The purpose of this study was to determine the influence of carbon from rice husks and wood grain as an absorbing agent of electrolyte solution on voltage strength and battery life. The method is to carbonize rice husks and wood grain, smooth them, and mix them with $\mathrm{NaCl}$ electrolyte solution. The novelty of this study is (1) The use of rice husk biomass and wood grain as the basic carbon absorbing material of electrolyte solution and (2) The use of four variations of salt and distilled water as electrolyte solutions.

\section{METHODS}

Figure 1 shows the battery fabrication process performed in this study. The materials used are rice husks, sawdust, distillation water, $\mathrm{NaCl}$, and 1.5 Volt used batteries. The electrolyte solution used is $\mathrm{NaCl}$ solution with $\mathrm{NaCL}$ percentages of $10,20,30$, and $40 \%$. In addition, a 1.5 Volt battery with $A B C$ brand is used as a comparison. The carbonization process of rice husks and sawdust is carried out at a temperature of $200^{\circ} \mathrm{C}$ for 30 minutes. After that the carbonization results are smoothed and mixed with several variations of electrolyte solution. The mixing result is then inserted into a clean battery and then the battery is assembled into a series.

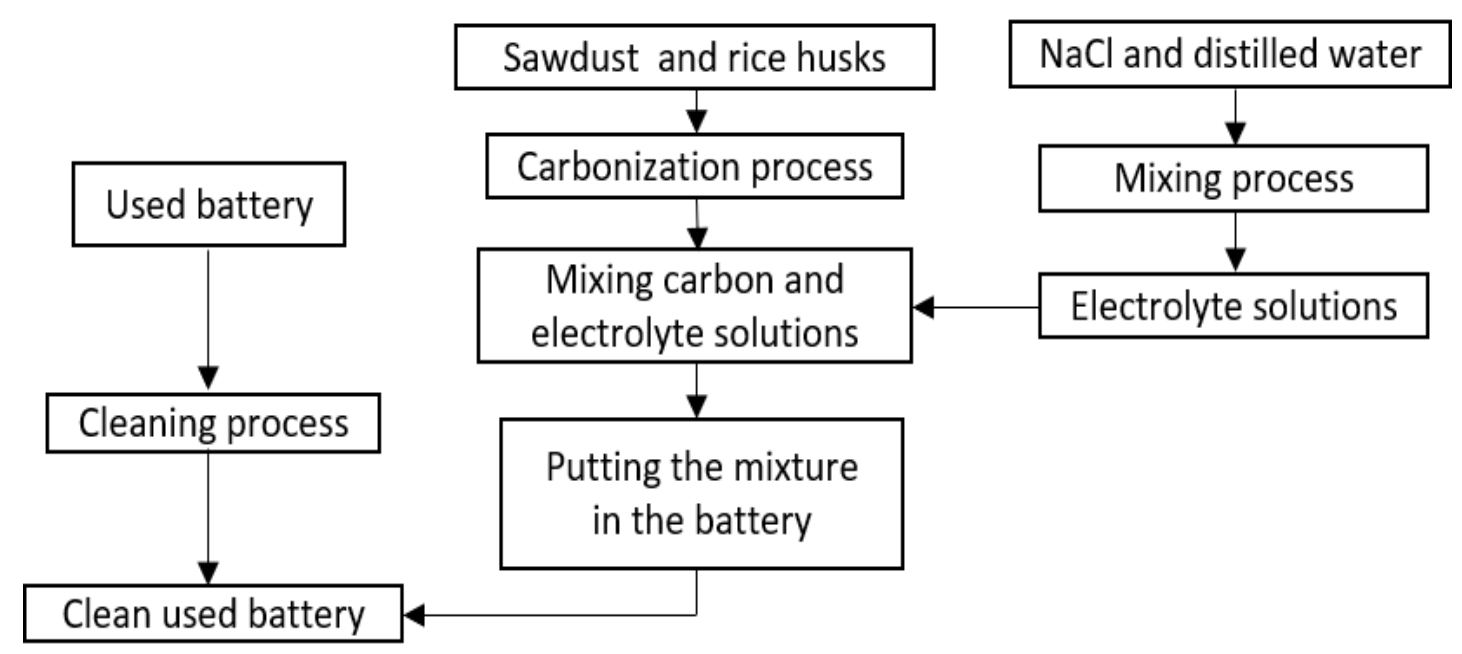

Figure 1 Battery fabrication process. 


\section{RESULTS AND DISCUSSION}

Figure 2a shows a used battery that has been filled with carbon rice husks and wood grain with variations of various electrolyte solutions. Figure $\mathbf{2} \mathbf{b}$ shows four batteries that have been compiled in series.

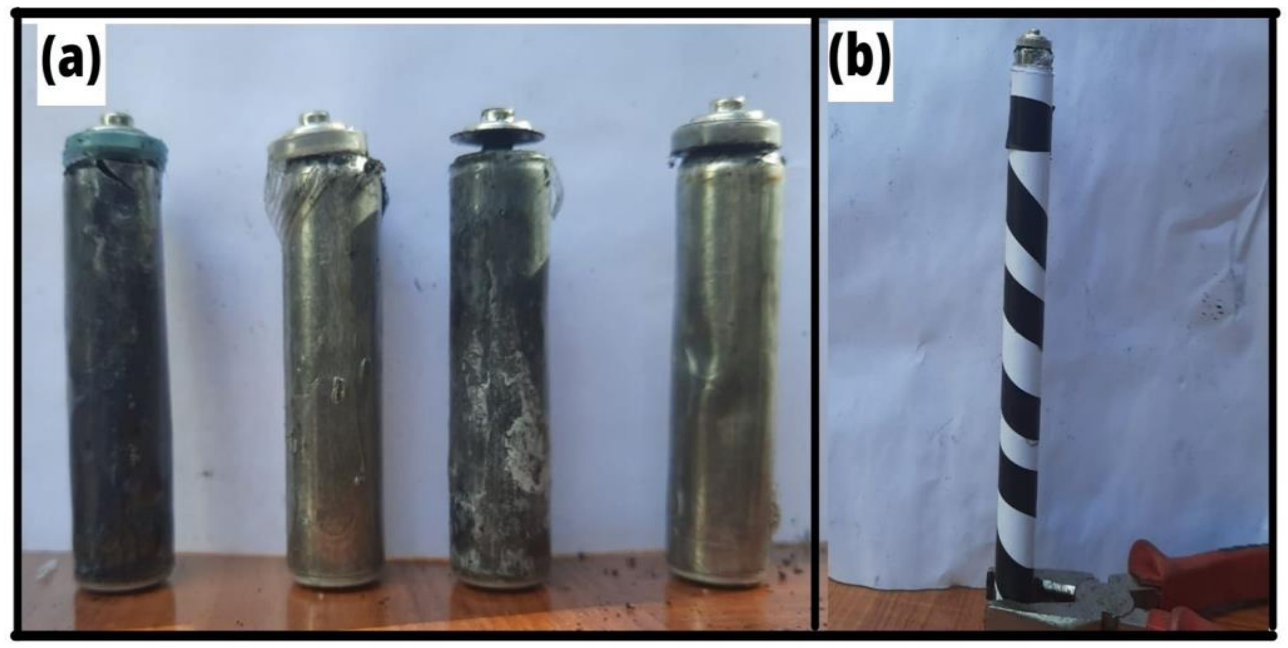

Figure 2. (a) Carbon-charged batteries and (b) Battery series arrangements.

\subsection{Voltage test with avometer}

Table 1 shows the results of battery voltage test using Avometer. Batteries with carbon from rice husks and sawdust produce an average voltage of 0.79 Volts. When compared to $A B C$ batteries that produce a voltage of 1.5 Volts, this battery still has a lower voltage of 0.71 Volts.

However, batteries with carbon derived from rice husks and sawdust are more environmentally friendly because these batteries do not contain harmful and toxic chemicals. In addition, the use of rice husks and sawdust can increase the selling price of the biomass while also utilizing biomass that is easily found. A battery with an electrolyte solution (10\%) produces the highest voltage, which is 0.85 volts.

This shows that the smallest salt concentration produces a larger battery voltage. However, at salt concentrations of 20,30 , and $40 \%$, the relationship between salt concentration and electric voltage is positively correlated. Thus, greater salt concentration can create greater stress. However, overall, the voltage size of each battery is relatively not very different.

Table 1. Battery voltage test results.

\begin{tabular}{cc}
\hline NaCl Percentage (\%) & Voltage (Volt) \\
\hline 10 & 0,85 \\
20 & 0,75 \\
30 & 0,77 \\
40 & 0,80 \\
Average & 0,79 \\
\hline
\end{tabular}




\section{CONCLUSION}

The effect of carbon derived from rice husks and sawdust has been evaluated. Based on this research, batteries with carbon derived from rice husks and sawdust produce less voltage than commercial batteries. However, batteries with carbon derived from rice husks and sawdust are more environmentally friendly because they do not use harmful chemicals. In addition, the use of rice husk biomass and sawdust can increase the selling price of the two biomasses. The smallest percentage of salt in the electrolyte solution actually produces the battery with the largest voltage. This shows that the greater the salt concentration in the electrolyte solution does not produce a greater voltage. However, on the whole, the battery voltage is relatively similar.

\section{ACKNOWLEDGEMENTS}

We thank to our Research Advisers, Panel of Examiners, Participants of the Study, The Institution - Universitas Pendidikan Indonesia -, and the Research Friends.

\section{AUTHORS' NOTE}

The authors declare that there is no conflict of interest regarding the publication of this article. The authors confirmed that the paper was free of plagiarism.

\section{REFERENCES}

Cao, W., Zhang, E., Wang, J., Liu, Z., Ge, J., Yu, X. and Lu, B. (2019). Potato derived biomass porous carbon as anode for potassium ion batteries. Electrochimica Acta, 293, 364370.

Ernawati, D., Arifudin, M., and Husodo, S. (2019). Baterai ramah lingkungan dari limbah serbuk kayu merbau ( Intsia bijuga) dan matoa ( Pometia sp .) ( Eco-friendly battery from Merbau ( Intsia bijuga ) and Matoa ( Pometia sp .) sawdust ). Jurnal IImu Teknol Kayu Trop, 17(1), 83-89.

Han, S. W., Jung, D. W., Jeong, J. H., and Oh, E. S. (2014). Effect of pyrolysis temperature on carbon obtained from green tea biomass for superior lithium ion battery anodes. Chemical Engineering Journal, 254, 597-604.

Jamilatun, S., Shakti, D., and Ferdiant, F. (2010). Pembuatan biocoal sebagai bahan bakar alternatif dari batubara dengan campuran arang serbuk gergaji kayu jati , glugu dan sekam padi. UPN Veteran Yogyakarta: Institutional Repository.

Jiang, Q., Zhang, Z., Yin, S., Guo, Z., Wang, S., and Feng, C. (2016). Biomass carbon micro/nanostructures derived from ramie fibers and corn cobs as anode materials for lithium-ion and sodium-ion batteries. Applied Surface Science, 379, 73-82.

Muhlisin, Muh., et al. (2015). Pemanfaatan sampah kulit pisang dan kulit durian sebagai bahan alternatif pengganti pasta batu baterai. Jurnal Rekayasa Dan Teknologi Elektro, 9(3), 137-47.

Yuliza, N., Nazir, N. and Djalal, M. (2013). Pengaruh Komposisi arang sekam padi dan arang kulit biji jarak pagar terhadap mutu briket arang. Jurnal Litbang Industri, 3(1), 21. 